\title{
アルミニウム粉末冶金の展望
}

武田 義信*

\section{A prospect of aluminum powder metallurgy}

\section{1.はじめに}

アルミニウム粉末治金（以下 $\mathrm{P} / \mathrm{M} \mathrm{Al}$ と称す）は, 1945年 Irmann によって偶然に発見され，ALCOA 社に よって1952年 AMP 合金として開発されたいわゆる SAPを第 1 世代とすると，1960年代の ARM による焼 結アルミニウムが第 2 世代，そして1980年代になって開 花した急冷粉末押出アルミニウム合金を第 3 世代と称す ることができる。第 1 世代の SAP が，酸化物分散強化 合金であったのに対し，第 2 世代の焼結アルミニウム は, ジュラルミン系合金を液相焼結と鉄系焼結機械部品 と同様の型押成型プロセスで作るといら材料そのものよ りも部品としての形を形成するプロセスにポイントがあ

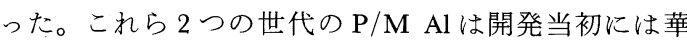
々しい未来を期待されてはいたが，現実には性能上の問 題や経済性の問題から他の粉末治金材料注どの成功を招 さめるには至っていない。特にわが国では米国と比較す ると焼結部品用に使用されるアルミニウム粉末は微々た るものであり，粉末治金工業界のみならずアルミニウム 工業界からもその飛躍が強く望をれていた。第 3 世代の $\mathrm{P} / \mathrm{M} \mathrm{Al}$ の登場はまさにこれに応光たものであり, 従来 の $\mathrm{P} / \mathrm{M} \mathrm{Al}$ の歴史にはない活発さで世界的に研究開発 が進みつつある。しかもわが国では通産省工業技術院産 業活性化技術研究開発補助金制度「アルミニ”ウム粉末治 金技術の研究開発」が昭和58年から 9 社の参加によって 開始され，産業界において十指に余る企業が開発にしの ぎを削るに至り，商業べースでの生産も民生用としては 世界に先駆けて開始されていることは衆知の通りであ る。本報では，最近の $\mathrm{P} / \mathrm{M} \mathrm{Al}$ の開発状況を紹介する と共に，市場性を含めた将来展望について述べる。

\section{2. $\mathbf{P} / \mathbf{M} \mathrm{Al}$ の技術開発}

\section{1 急冷凝固技術}

$\mathrm{P} / \mathrm{M} \mathrm{Al}$ に最も大きなインパクトを与えたのは，急冷
凝固（以下 RS と称す）技術による粉末製造である。特 に超急冷と称される $10^{4} \mathrm{~K} / \mathrm{s}$ 以上の冷却速度でのアモル ファス合金や準安定相合金の研究は，アルミニウム合金 でも新しい合金の開発を触発した。

RS の効果は Grant によると次のように分類される1)。

・粒界偏析の低減

- 偏析抑制

- 偏析性合金元素の有効利用

・結晶粒度の広範囲な制御（非晶質相の結晶化では $0.01 \mu \mathrm{m}$ ，結晶質相では0.5 $\mu \mathrm{m}$ まで)

・新しい相，準安定相の生成

- 非晶質相合金の生成（偏析のない全く新しい合金） アルミニウム合金に执いて，この RS 効果の利用を考 えるとさまざまな新合金開発の可能性が想定される。ア ルミニウムは他の合金元素と金属間化合物を作りやす く，粗大で脆い金属間化合物の存在によって機械的特性 が損われる場合が多かったが，それを微細化したり，過 飽和固溶させたり，準安定な別の相にすることで大きな

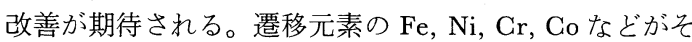
の代表例であり，平衡状態図を図 1 図 3 亿示す。

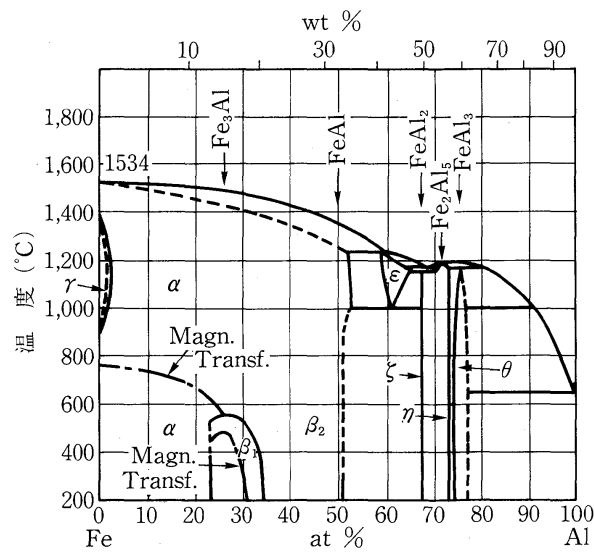

図 $1 \mathrm{Al}-\mathrm{Fe}$ 平衡状態図

* 住友電気工業(侏)（伊丹市)。Sumitomo Electric Industries, Ltd (Itami). 


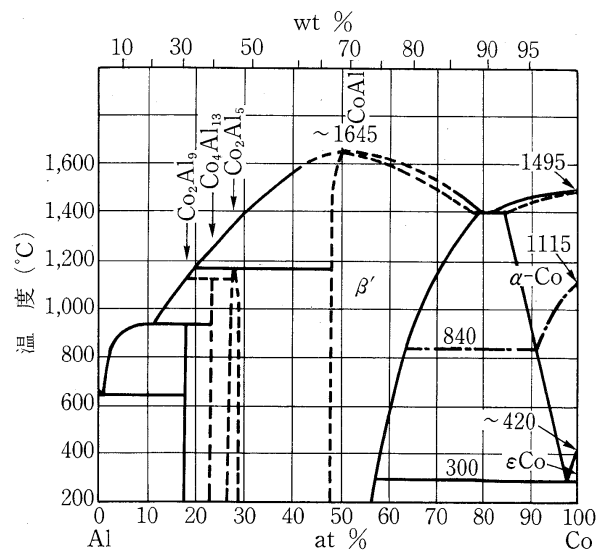

図 $2 \mathrm{Al}-\mathrm{Co}$ 平衡状態図

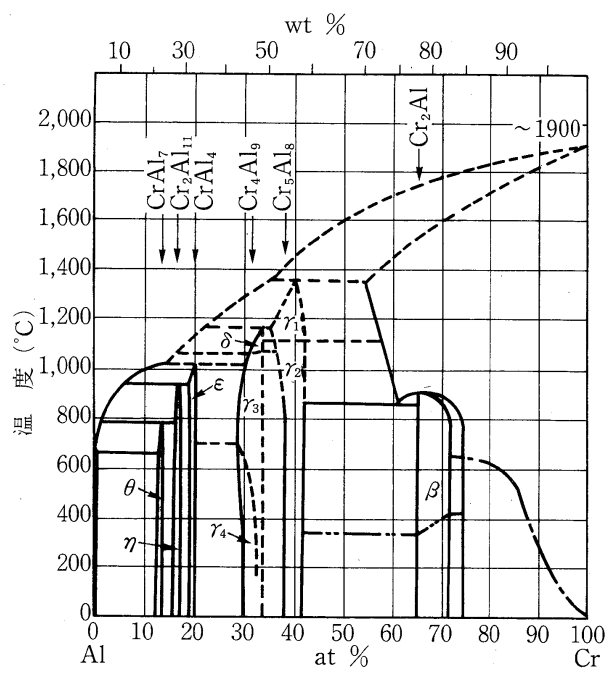

図 $3 \mathrm{Al}-\mathrm{Cr}$ 平衡状態図

また，化合物は作らないものの，固溶度が小さく，共 晶を形成する合金で，晶出物を RSによって微細にする ことで，物理的特性を改善したり，高組成の合金化時に 生じる偏析を RSによって避けることでより高組成の新 しい合金が得られる可能性がある。図 4 に示す $\mathrm{Al}-\mathrm{Si}$ 合 金では，過共晶合金の初晶 $\mathrm{Si}$ の微細化がそれに相当す る。図 5 に示すように, $\mathrm{Al}-20 \% \mathrm{Si}$ の過共晶合金でもき わめて微細な Si の初晶が得られること，乙かも冷却速 度がいわゆる超急冷域でなくともこのような微細な晶出 物が得られることは, 化学組成のみならず, 結晶組織そ のものの違いによって新しい機能を有するアルミニウム 合金を生む可能性がある。

このような急冷凝固によって粉末を製造する方法につ いては，すでに多くのアイデアが実施されており，それ らについてまとめた報告も数多く出されている2)。現在

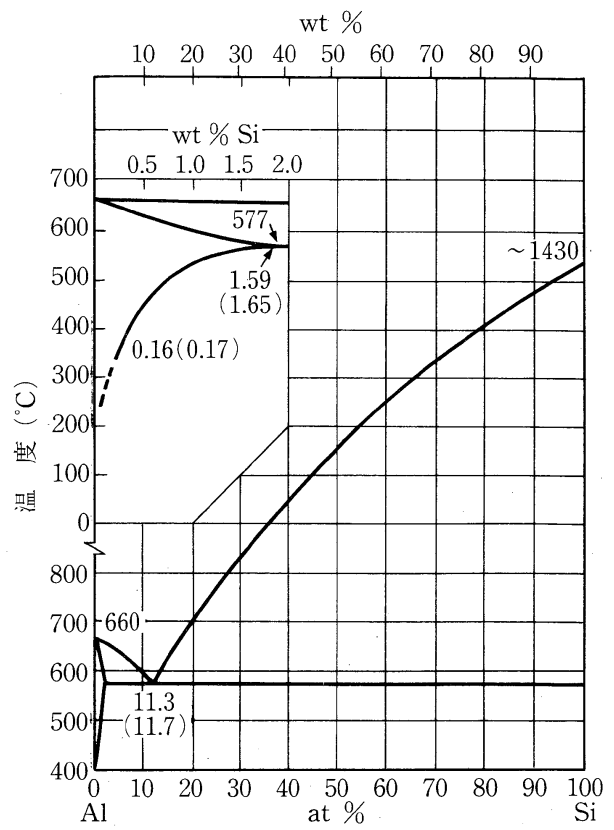

図 $4 \mathrm{Al}-\mathrm{Si}$ 平衡状態図

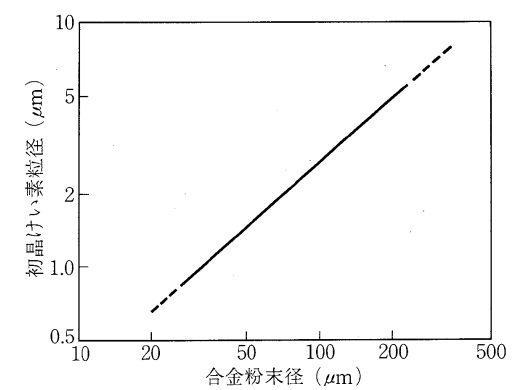

図 5 エアーアトマイズされた $\mathrm{Al}-20 \% \mathrm{Si}$ 合金粉中 の初晶けい素の粒径

公表されているアルミニウム急冷粉末の製造方法は，次 の通りである3)。

$$
\begin{aligned}
& \text { エアーアトマイズ : ALCOA } \\
& \text { ガスアトマイズ : VALIMET }
\end{aligned}
$$

回転急冷法 : Pratt \& Whitney, 住友電工

噴霧片ロール法 : 住友軽金属

噴霧双ロール法：神戸製鋼

超音波ガスアトマイズ：MIT

工業的に確立されている方法は，エアアトマイズ法とガ スアトマイズ法であり経済性も有利であるが，合金系に よっては冷却速度や粉末表面の酸化の点から改善が必要 である。その他の方法はこの問題を改善する目的で開発 されているが，各々にメリット，デメリットがあり，今 後工業的レベルでの新しい急冷粉末の製法の確立が期待 されている。アルミニウム合金粉末製造の取扱い上の安 
全性についてはアルミニゥム自身の易酸化性の性質のた め, 通常の粉塵爆発以上に注意が払わ札てきた。最近, 寺崎, 高橋らの爆発性に関する調査結果も発表され4), アルミニウム急冷凝固合金粉末製造の周辺技術も進歩し つつある。

\section{2 機械的合金化（Mechanical Alloying）技術}

機械的合金化技術は，酸化物分散強化合金，特に二ッ ケル基超合金に $\mathrm{Y}_{2} \mathrm{O}_{3}$ を分散させた $\mathrm{MA}-754$ や $\mathrm{MA}^{-}$ 6000の開発 5 によって，その実用性とポテンシャルが認 識され，アルミニウム合金にも適用してまったく新しい アルミニウム合金を作る試みがなされている6),7)。図 6 に示すアトライターを用いた機械的合金化のメカニズム には，酸化物のよらに本来金属中に溶け込むことがなく 溶解法で作ららとすると比重差によって偏析したり，凝 集したりして微細に分散することのできない第二相成分 を図 7 のように機械的に分散し，マトリックスに埋め込 むことと，合金元素そのものを微粉砕し，マトリックス 中に埋め込むことで合金化させることの二つがある。マ クロ的に見れば，機械的合金化のプロセスは粉砕之凝着 凝集（冷間接合）であるが，これにさらに化学的な反応 も伴ら。特にアルミニウム粉末の場合, 雾囲気中の酸素 が塑性変形によって生じたアルミニウム粉末粒子の新生 面で反応し酸化膜を作り，この酸化物が粉砕されて微細 な酸化物としてマトリックス中に分散される。アルミニ ウム炭化物 $\left(\mathrm{Al}_{4} \mathrm{C}_{3}\right)$ も熱的に安定であるため，機械的 合金化によって生成させることが行われている⿸广 方，アルミニウムマトリックス中に，あらかじめ aluminide の形で合金を分散させることで，固溶強化で はなく分散強化を，任意の金属間化合物 (aluminide) 微粒子で実現する試みもされている。また，タングステ ンやモリブデンのようにアルミニウムと比較するときわ めて融点が高く，また比重差の大きな合金元素を合金化 させる手段として試みもなされてお打り帛,10)，従来の溶解 法を基本とし，急冷凝固法を含む多くの方法をもってし

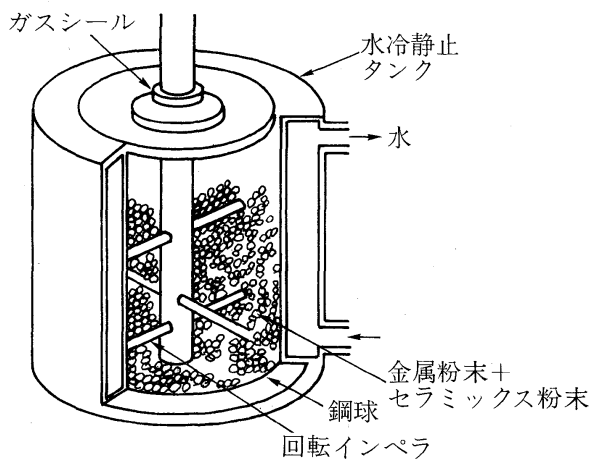

機械的合金化法

図 6 アトライターの構造
複合金属粉末

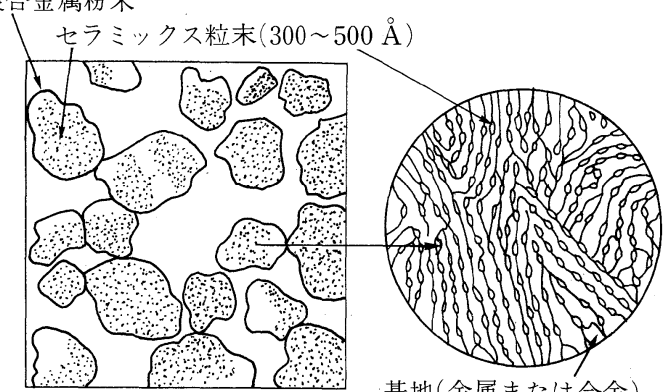

基地 (金属または合金)

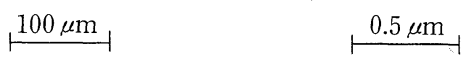

粉末の性状とその組織

図 7 MA 合金粉末

ても製造し得なかったまったく新しい合金が今後も生ま れてくる可能性があり，急冷凝固技術之共に原料粉末の 段階での大きな技術革新の上でのキーテクノロジーであ ると言える。

\section{3 成形固化技術（Consolidation 技術）}

一般的な粉末治金法の型押焼結プロセスが $\mathrm{P} / \mathrm{M} \mathrm{Al}$ に量産レベルで適用できるようになって以来10年以上の 歳月が経ているが，この技術で得られるアルミニウム合 金の強度特性は溶製アルミニウム合金を越えることはで きず，また新しい急冷凝固合金粉末やMA 合金粉末の 成形焼結にも適していない。一般にアルミニウム合金粉 末の表面は，図 8 のように100 ̊ 前後の酸化物によって 覆われて括り，この酸化膜がバリヤとなって拡散を阻む ため，焼結が進行せず，十分な強度が得られない。ま た，従来用いられていた焼結温度は，準安定相を有する 合金粉末の焼結には高温すぎ，晶析出物の粗大化を招い たり，著しい強度の低下をもたらす。このため，なるべ く低温で残留空孔なく成形固化する新しい技術が必要々 なった99。物理的に粉末表面の酸化膜を破壊するための 応力は, 種々の形で付与することが考兄られ, 次のよう な方法が試みられている。

(1)熱間押出，(2)摩擦押出成形（コンフォーム), (3)粉

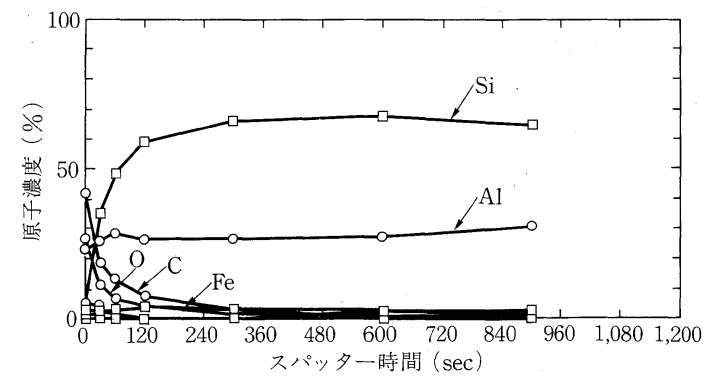

図 $8 \mathrm{Al}-\mathrm{Si}-\mathrm{Fe}$ 合金粉末表面のオージェ分析結果 (スパッター速度 $120 \mathrm{sec} \fallingdotseq 100 \AA$ ) 


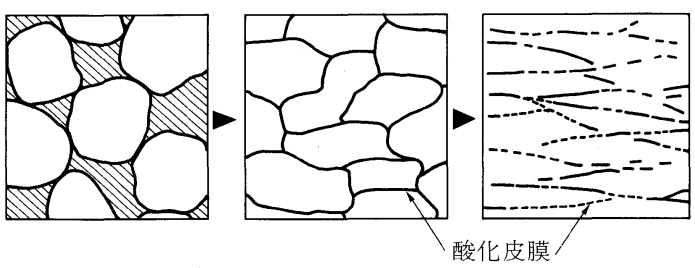

図 9 粉末の成型固化

末圧延，(4)ホットプレス，(5)熱間鍛造，(6) HIP，(7) 衝撃成形, 8通電 (放電) 焼結

このらち最も普及しつつあるのが，熱間押出法である。 図 9 に示すように粉末粒子が変形し, 新しい表面が生じ るにはせん断変形が最も有効であり，ホットプレスや HIP 法等の方法と比較して，せん断変形をより多く生 じさせる熱間押出法は強固な粒子間結合を得るには適し ていると言兄る。同様の理由で摩擦押出成形法も形状に よっては啇した方法である。しかし最近，HIP ${ }^{11)}$ や熱間 鍛造 ${ }^{12)}$ によても合金組成によっては押出法並みの機械 的特性が得られるとの報告があり，応用分野ごとに種々 の Consolidation 法が使い分けられてゆくものと思われ る。また, 単に粉末粒子を固めてバルクを作るだけの Consolidation ではなく，部品形状の成形加工も含めた 本来の粉末治金技術としての Consolidation 法が重要性 を増していると思われる。

\section{3. 合金開発}

$\mathrm{P} / \mathrm{M} \mathrm{Al}$ 合金は，次のような特性別の分類を行うこと ができる。

(1)高力合金 (高引張強度), (2)高剛性合金（高ヤング 率), (3)耐熱合金（高温高引張強度・高クリープ強 度), (4)耐摩耗合金, (5)高耐応力腐食割れ性合金 この 5 種類の機械的高強度合金の他にさらに次のような 特殊な合金も提供されている。

(1)低放射化高強度合金, (2)高電気伝導耐クリープ合 金, (3)高潤滑性軸受合金, (4)低熱膨張高熱伝導合金, (5)超塑性合金

$\mathrm{P} / \mathrm{M} \mathrm{Al}$ 合金の強化メカニズムは, $\mathrm{Starke}^{13)}$ によって まとめられている通り, 室温から中温域ではHall Petch の結晶粒径 $d$ の $1 / 2$ 乗則

$$
\sigma_{y}=\sigma_{i}+K_{y} \cdot d^{-1 / 2} \quad\left(\sigma_{y}=\text { 降伏応力 }\right)
$$

の関係に加之て, 固溶強化 $\left(\sigma_{i}\right.$ の増加）と分散強化 （Ky の増加）が関与している。固溶強化は, 急冷凝固 等による過飽和固溶体による強化が予想されているが, 現実には必ずしも過飽和な固溶体が形成されていなかっ たり, Consolidation 中の加熱等により固溶体から第 2 相が析出されるため，平衡相合金よりも大きな効果が得 られるとは限らない。急冷凝固合金からの遷移元素化合
物の析出相は, $\mathrm{Cu}, \mathrm{Mg}, \mathrm{Zn}$ 等の合金元素による析出相 と異なりマトリックスと非整合であるため, Orowan looping 機構によって $\sigma_{i}$ を大きくする効果が大きいこと が考えられる。また，分散物によって Subgrain boundary がピンどめされる場合には再結晶が阻げられ微細 結晶粒による強化が保たれる。

高温では転位の上昇や粒界・体積拡散, 粒界すべり等 が変形メカニズムであるため，高温でも拡散しない安定 な合金元素や分散物相が寄与する。

これらの基本的な強化のメカニズムを前提にし，さら に延性や耐摩耗性, 耐応力腐食割れ性を得るための観点 からの合金設計が実用合金には必要である。

\section{1 高力合金}

高力合金は，展伸材では $\mathrm{Al}-\mathrm{Zn}$ 系の7075合金が代表 格であるが，米国ではCo 等を添加した7090，7091合金 がまず開発され ${ }^{14)}$, 最近強度を保ちつつ破壊じん性 $\mathrm{K}_{\mathrm{IC}}$ を7090の約 2 倍の $44 \mathrm{MPa} \mathrm{m}^{1 / 2}$ に改善した GW67合金が 開発されている15)。これらの合金は常温での引張強さが $600 \mathrm{MPa}$ の程度であり，展伸材の7075の $\mathrm{T} 73$ 材の 500 $\mathrm{MPa}$ と比較すると約 $100 \mathrm{MPa}$ 高いが, 引張強さそのも のは画期的なレベルではない。前述の通産省のプロジェ クトでは700 MPa を目標とし，すでに $\mathrm{Al}-\mathrm{Zn}$ 系で目標 が達成されている。700 MPa 以上の強度が他のじん性 やヤング率と共に得られるよらになると, 比強度の点か らきわめて優れた材料となり，鋼を代替することができ るケースが増えることが期待できる。米国ではこのよう な高力合金は主として航空機の機体構造材である7075や 2014等の改良材として開発されているのに対し, 日本で はむしろ自動車や産業機械用構造材の鋼の代替他等が期 待されている点が違っている。しかし，次世代航空機基 盤技術研究, 通称 ATP (Advanced Turbo Prop) や FSX（次期支援戦闘機）の国産化, 宇宙往環機等のプロ ジェクトが知られているよらに, 将来独自の航空宇宙産 業用市場が育つ可能性もあり, 国際競争力のある高力合 金のニーズは強い。

\section{2 高剛性合金}

高剛性合金は, 機械構造部品の設計上引張強度や疲労 強度だけでは負荷時の弾性変形等の問題が生じることに 対する要求から開発が進められている。図10に見られる ように,アルミニウムの剛性は他の金属に比較すると低 く，少なくとも $100 \mathrm{GPa}$ 以上要望されている。剛性に及 ぼす合金元素添加量の効果を図116)に示す。添加合金元 素量の増加と共に剛性は向上するが，リチウムのよらに 数\%以上の添加が不可能な合金元素は効果が大きくても 実際には絶対値として大きな向上を期待できない問題が ある。 $\mathrm{Al}-\mathrm{Si}-\mathrm{Fe}$ 系合金ではすでに $100 \mathrm{GPa}$ 以上の值が 得られており ${ }^{17)}$ ，また図12に示すように7075等の従来合 


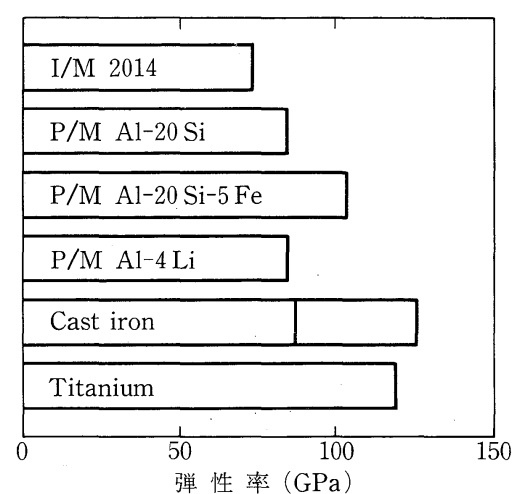

図10 各材料の弾性率

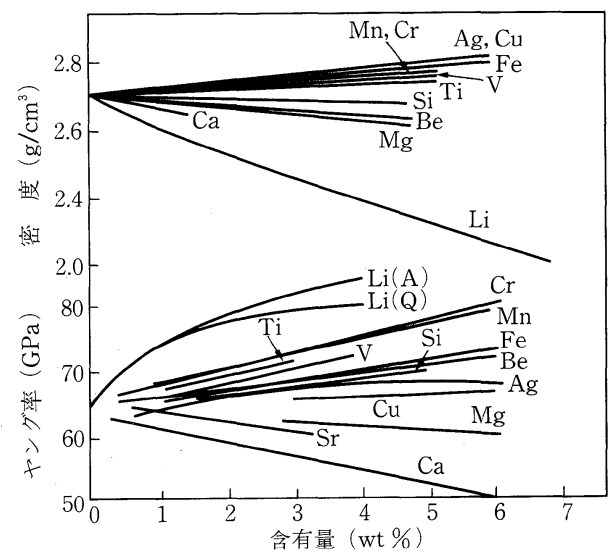

図11 アルミニウムの密度およびャング率に及ぼす 添加元素の影響

(Q) 溶体化処理材, (A) 時効処理材, 他は鋳 造材

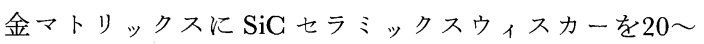
30体積\%添加した合金に扎いては, $130 \mathrm{GPa}$ 以上のヤン グ率が得られることが発表されている18)。マトリックス のヤング率を従来合金の70 GPa のレベルから100 GPa のレベルに向上させることによって, 同じ130 GPaのヤ ング率を得るために添加する強化ウィスカーや粒子の量 は低減することが可能になると考兄られ，経済性や被削 加工性の点でより優れた高剛性合金が期待できる。

\section{3 耐熱合金}

而熱合金は，従来 $200^{\circ} \mathrm{C}$ 以上では十分な機械的強度が 確保できないといらアルミニウム合金の限界を越えた新 しいアルミニウム合金によって, チタンや鉄の代替を可 能にすることを狙らものである。従来耐熱アルミニウム 合金として開発されたのは主として，エンジンのピスト ンに使用する鋳造合金で, $\mathrm{Al}-\mathrm{Si}-\mathrm{Cu}-\mathrm{Mg}$ 合金に $\mathrm{Ni}$

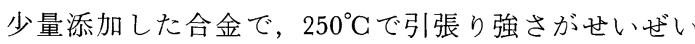
$170 \mathrm{MPa}$ であった ${ }^{19)}$ 。耐熱性の向上には, 高温でも安

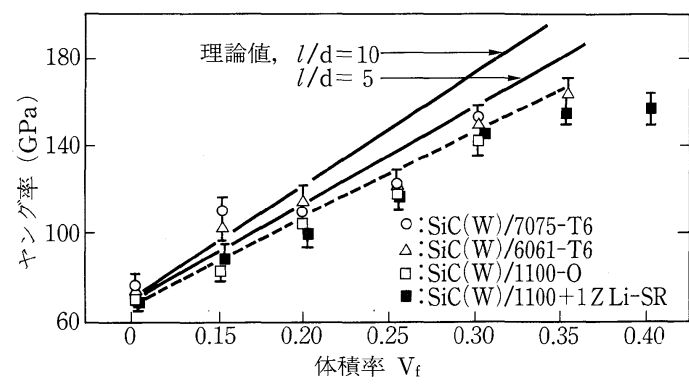

図12 押出成型体のヤング率, 引張強さと $\mathrm{SiC}$ 体 積率 $\mathrm{V}_{\mathrm{f}}$ の関係

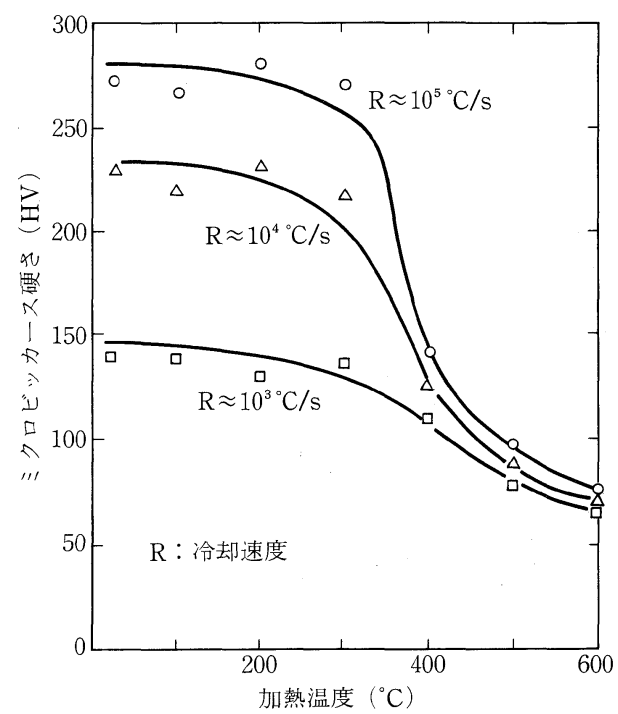

図13 $\mathrm{Al}-8 \mathrm{wt} \% \mathrm{Fe}$ 急冷凝固粉末の加熱温度と硬さ の関係

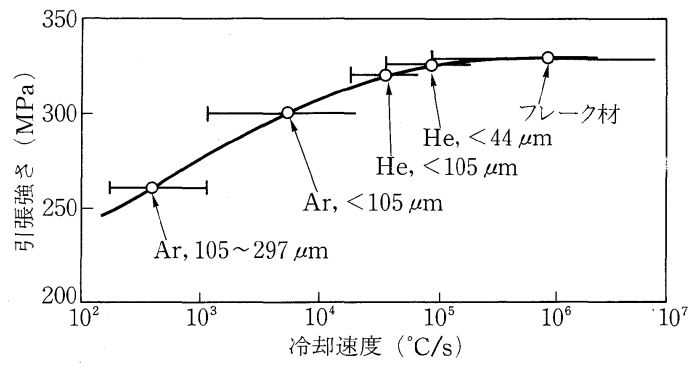

図14 $\mathrm{Al}-8 \% \mathrm{Fe}$ 合金押出材の冷却速度と引張強さ の関係

定な分散物の添加が必要であり，遷移元素を主としたア ルミナイドを微細に分散させる方法や酸化物, 炭化物, ちっ化物等を分散させる方法が $\mathrm{P} / \mathrm{M} \mathrm{Al}$ においては研 究されている。米国では $\mathrm{Al}-\mathrm{Fe}-\mathrm{Ce}(\mathrm{CW79})^{20)}, \mathrm{Al}-\mathrm{Si}^{-}$ $\mathrm{Mn}$ (CS50, CW63), $\mathrm{Al}-\mathrm{Fe}-\mathrm{V}-\mathrm{Si}^{21)}$ や $\mathrm{Al}-\mathrm{Cr}-\mathrm{Zr}^{22}$ 等の 多元系合金が発表され，わが国でも $\mathrm{Al}-\mathrm{Fe}$ 系を中心と 


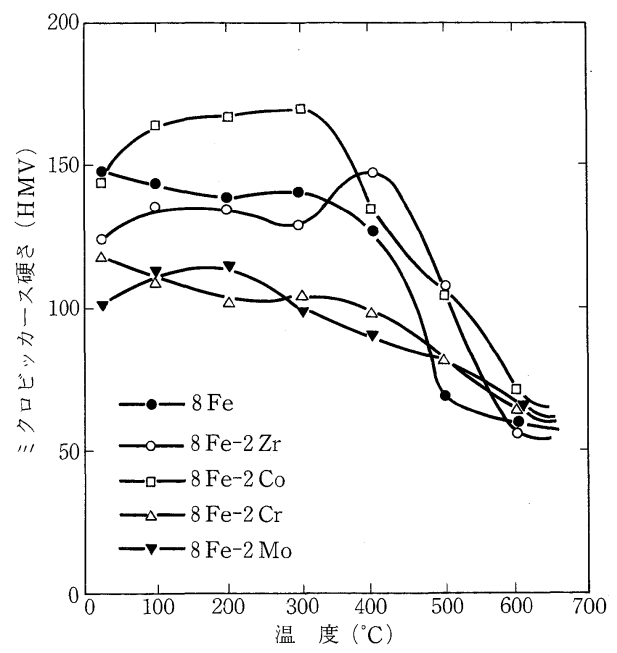

図15 $\mathrm{Al}-8 \mathrm{Fe}-2 \mathrm{X}$ 系合金の硬さ

して系統的な研究が発表されている23),24),25)。このよう な耐熱合金の開発目標值は，300において $300 \mathrm{MPa}$ 程 度と考えることが一般化しており, 従来の耐熱アルミニ ウム合金の約 2 倍以上の高温強度である。図13, 図14 23) に示すよらに $\mathrm{Al}-\mathrm{Fe}$ 系合金に扎いては, 冷却速度の増 大と共に強度が高くなることが知られている。また超急 冷粉末製造技術の進歩によって, 非晶質でも結晶質でも ない準結晶相が生ずることが報告されており，またこの ようなまったく新しい相は consolidation 中にある程度 分解する可能性はあるものの従来にはない特性を示す可 能性も期待される27)。consolidation 中の強度低下は，急 冷による準安定相合金の宿命とも言える。一方，高温高 強度合金は高温で変形抵抗が高いために consolidation が難しく，より高温での加工が必要になるというもう一 つの宿命的矛盾があり，プロセスの最適化と共に合金設 計上での工夫が必要である。図15に示すように高温時効 によって析出硬化する $\mathrm{Zr}$ 等を添加することや, 溶質原 子の高温でのクラスタリングや粗大析出を妨げる効果 ${ }^{28)}$ を示すクロムを添加すること等がその解決の手がかりに なると考えられる。

\section{4 耐摩耗合金}

耐摩耗合金は, $\mathrm{Al}-\mathrm{Si}$ 溶解鋳造合金より耐摩耗性の優 れた合金が得られている。 $\mathrm{P} / \mathrm{M} \mathrm{Al}$ 合金は特に $\mathrm{Al}-\mathrm{Si}$ 合 金の場合，耐摩耗成分である Si 粒子の粒径が $20 \mu \mathrm{m}$ 以 下であるために Si 粒径が $20 \mu \mathrm{m}$ 以上と大きい溶解合金 と耐摩耗性の点で比較するとあまり期待できないとする 見方もある ${ }^{29)}$ 。耐摩耗性そのものは $\mathrm{Si}$ 粒子以外の要素 で改善できるらえ，P/M Alの自由度の大きさ，すなわ ら合金組成の選択範囲の広さ, 異種而摩成分の添加の容 易さ，機械的強度そのものの高さ等の点でやはり従来の 溶解合金とは比較にならぬ可能性を秘めていると言らべ

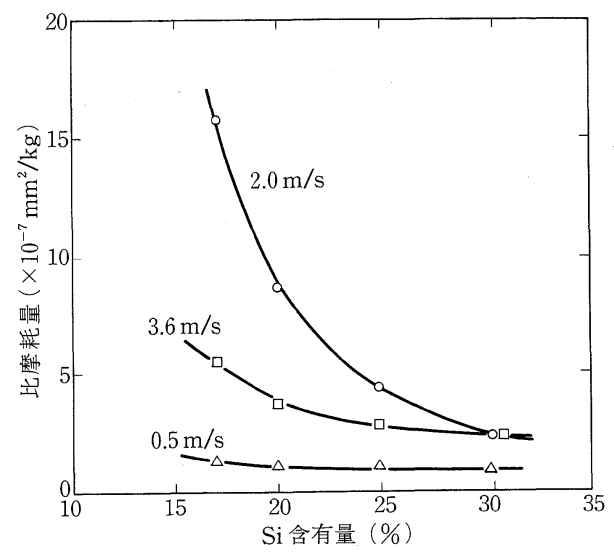

図16 耐摩耗特性に及ぼす Si 添加量の影響

きである。図16に Si 量と耐摩耗性の関係を示した。耐 摩耗合金の用途は千差万別であり，用途に応じた合金設 計が必要と思われるが，コンプレッサー部品として使わ れはじめたベーン用材料の場合には ${ }^{30)}$, 耐摩耗性や強度 と同時に熱膨張係数が小さい点が重要な特性として活か されており,今後軸受合金等も含めて $\mathrm{P} / \mathrm{M} \mathrm{Al}$ の自由 度が発揮されて新しい合金が開発され，用途開発も進む ものと考えられる。

\section{5 高耐応力腐食割れ性合金}

高耐応力腐食割れ性合金は, 高力アルミニウム合金の 航空機用機材として要求されているものであり, 応力腐 食割れ特性のみを目標とするのではなく，あくまでも高 力合金の耐環境信頼性の評価の一つと考えた方が妥当で ある。このため $\mathrm{Al}-\mathrm{Zn}$ 系合金を中心に研究が行われて いるが，今後高力合金の開発の進展と共にこの特性に関 する研究は本格化するものと思われる。

\section{6 その他の特殊な用途の機能性合金}

その他の特殊な用途の機能性合金についてはその名称 をすでにあげたが，このうち低放射化高強度合金につい て紹介する。

中性子が強力に照射される環境下では, 材料の放射化 が問題になり, 誘導放射能減衰の早い元素で材料を構成 する必要がある。一方, 実際の構造部材としては, 核融 合炉容器の場合には誘導電流を小さくするために電気抵 抗を上げる必要性や, 電磁力に耐兄るための強度特性等 が必要である。これらの条件を満たすために， Be, Li， $\mathrm{Mg}, \mathrm{Si}, \mathrm{V}, \mathrm{C}$ 等の合金元素で構成される合金の可能性が 検討されている31),32)。アルミニウム合金による核融合 装置の実現には時間を有すると思われるが，P/M Al に よる画期的な新材料開発の好例として期待される。

\section{4. 今後の展望}

第 3 世代の P/M Al は未だ実用化が始まったばかり 
であり，技術的にも経済性の点でも未熟な段階にある。 米国で $\mathrm{RS} \mathrm{Al}$ 合金について行われた市場アセスメン ト33)を見ると経済性の問題が普及の大きな課題であると 指摘されて打り，わが国においても同様の点が指摘され ている。しかし宇宙航空用材料，特に国防上の戦略的な 材料として経済性の多少の犠牲のもとに開発を進めてい る米国と比較すると，わが国の場合は当初から民生用自 動車関連部品を主たるターゲットにした開発が進んでい るので, 実質的にはかなり経済性の課題は解決されつつ あると言える。新プロセスによる新素材の経済性の問題 は常に生産量が大きくならないと安くならず，価格が高 いと需要が拡大できないといら「鶏と卵」の関係にあり， このサイクルから脱するには製造側の努力は言らまでも なく，需要家側の新しい設計による有効な利用方法の開 発が大いに期待される。

特性の点から反ると, 当初ターゲットとされた強度特 性のほとんぞは達成されつつあり, 実用面から必要な総 合的な特性のバランスが次の課題になっている。たと兄 ば高力合金で高剛性，高耐応力腐食割れ性の合金は未だ 得られていないし，高耐熱合金で高強度，高剛性，高耐 摩耗性, 低比重の合金も得られていない。このような要 求特性の組み合せは多くの場合相矛盾する要求の両立が 求められており, 従来の溶製法では実現が不可能である がゆえに $\mathrm{P} / \mathrm{M}$ 法にその解決が期待されている。 $\mathrm{P} / \mathrm{M}$ 法 にとってもこのような問題の解決は容易ではないが，プ 口セス，合金組成，結晶粒や組織の制御等の自由度の高 さが解決への有力な手段とならう。

今後, 参入企業, 研究者の増大によって, 特定市場に 集中することなく，より広い視野での多様な開発が進み，

$\mathrm{RS} \mathrm{P} / \mathrm{M} \mathrm{Al}$ の裙野が広がり, 文字通り素材として広汎 な産業分野に普及することを期待したい。

本報告の一部は，通産省工業技術院産業活性化補助金 によるアルミニウム粉末治金技術研究組合の研究開発の 一環として行われたものである。

\section{参 考 文 献}

1） N. J. Grant：第 4 回次世代産業基盤技術シンポジ ウム金属複合材料技術予稿集，財次世代金属複合 材料研究開発協会 (1981).

2）黑石, 明智：軽金属, 34 (1984), 537.

3）日経メカニカル (1986) , 10-6, 60.
4）寺崎, 高橋, 他：機械技術研究所，所報40（1986）, 284.

5) J. S. Benjamin: Met. Trans., 1 (1970), 2943.

6) J. S. Benjamin and R. D. Schelleng: Met. Trans., 12A (1986), 1827.

7) G. Jangg, F. Kuther and G. Korb: Aluminum, 51 (1975), 641.

8) V. Arnhold and J. Baumgarten: P/M Int., 17 (1985), 168.

9）後藤，小林：軽金属学会，第71回講演会概要集 (1981), 97.

10）師岡，湯浅 : 同上, (1981), 99 .

11）犬丸，山内：住友軽金属技報，26 (1985)， 57 .

12）大㭇，河野，他：粉体粉末治金協金昭和 61 年度秋 季大会講演概要集, (1981)，40.

13) E. A. Starke and J. A. Wert: High Strength Powder Metallurgy Aluminum Alloys II, AIME. (1985), 3.

14) E. Lavernia, B. Poggiali et al.: J. Metals., (1985), 35.

15) G. J. Hildeman, L. C. Labarre et al.: High Strength Powder Metallurgy Aluminum Alloys II, AIME (1985), 25.

16）古川，美浦，他：日本金属学会報，23（1984）, 172.

17）明智：機械技術，No. 3, (1986)，20.

18）坂本：第 3 回次世代産業基盤技術シンポジウム 金属複合材料技術予稿集，(財)次世代金属複合材料 研究開発協会, (1980).

19）塩田：軽金属, 21（1971）, 670.

20) Y. Kim and W. M. Griffith: Rapidly Solidified Powder Aluminum Alloys, (1984) 485.

21) D. J. Skinner and K. Okazaki: Scripta Met., 18 (1984), 5.

22) G. J. Marshall et al.: Mat. Sci. Tech., April (1986).

23）淽江，佐野：住友軽金属技報，（1985）， 75 .

24）大家, 安倍：軽金属学会 第69回講演会概要集, (1985), 85.

25）小谷, 黒石 : 同上, (1985), 60.

26) D. Shechtman. I. Blech et al.: Phy. Rev. Let., 53 (1984), 1951.

27) F. H. Froes: J. Metals, No. 8 (1986), 33.

28) W. S. Miller, I. G. Polmer: Met. Powder Rep., Oct. (1986), 761.

29）大畠, 福井：日本金属学会会報, 24 (1985), 307.

30）天野, 小谷, 他：住友電気, 130 (1987), 1 9.

31）小谷, 武田, 他：プラズマ核融合学会第 3 回秋季 講演会予稿集，(1986)，152.

32）里, 高橋, 他: 同上, (1986), 153.

33) E. Lavernia, B. Poggiali, I. Serv, J. Clark, F. Katrak, and N. Grant: J. Metals., No. 11 (1985), 35. 